\title{
STUDY ON MORBIDITY AMONG UNDER-FIVE CHILDREN OF A RURAL AREA OF MANIPUR, THANGA: A CROSS-SECTIONAL STUDY
}

H. Nirendrakumar Singh, H. Sanayaima Devi, Y. Manihar Singh

1. Assistant Professor. Department of Community Medicine, JNIMS, Porompat.

2. Associate Professor. Department of Community Medicine, RIMS, Imphal.

3. Professor. Department of Community Medicine, RIMS, Imphal.

\section{CORRESPONDING AUTHOR:}

Dr. H. Nirendrakumar Singh,

Thangmeiband Lairenhanjaba Leikai,

Near Fishery Gate, Lamphel, Imphal,

Manipur, India, Pin- 795004.

E-mail: hnirendra10@gmail.com

ABSTRACT: BACKGROUND: Children are the most precious assets of a country and their health status is highly reliable index of nation's health. Major causes of deaths in the age group 0-5 years are preventable. OBJECTIVE: To determine morbidity pattern among under-five children in the area and to assess its association with some selected variables METHODS: A crosssectional study was conducted among under-five children in the village from September to December 2007. A sample size of $390\left(13^{*} 30\right)$ was selected and participants were examined after interviewing mother or care taker. Chi square test was applied for significance in the difference. RESULTS: Out of 390 under-five children 92.3\% were sick in the last 3 months of visit. Occurrence of illness was minimum (77.9\%) in age under one year as compared to other age categories ( $p=0.0001)$. Majority of them $(83.6 \%)$ were suffering from ARI with episode of 2.6/child in last 3 months. CONCLUSION: ARI is the commonest morbidity in the rural area of Manipur however the effect of flood on morbidity of under-five has to be studied further.

INTRODUCTION: The health status of children is highly reliable index of nation's health and is the most precious assets of a country and no country can afford to neglect the rights and health needs of a child. Of 2.2 billion children in the world, UNICEF estimates that 1.9 billion lived in developing world; one billion of it lived in poverty \& deprived of at least one of seven amenities considered to be basic rights as shelter, water, sanitation, schooling, information, health care and food.(7) Major causes of deaths in the age group 0-5 years are preventable.(6) The seasonal patterns of morbidities in preschool children in Lucknow as annual incidence rate per 100 child year for respiratory, diarrhea, skin disease and pneumonia were 167, 79.9, 30.6 and 9.6.(1) The present study is conducted at Thanga Village, Bishnupur District, Manipur to see the morbidity pattern among under-five children in the area.

MATERIALS AND METHODS: A cross sectional study was carried out during September to December 2007, among under-five children at Thanga Village - only island in Loktak Lake, the only fresh water lake in the North East India. Sample size was calculated based on $50 \%$ prevalence rate (3) as similar study considering the methodology and recall period of three months were lacking. The calculated sample size is 331 at $11 \%$ allowable error and at $5 \%$ significance level, however rounded to 390 as there are 13 leikais in the village. Sampling frame was obtained from AWW of each leikai (cluster) and selects 30 children randomly from each cluster. Verbal consent was sought before involvement. 
Literate mothers are those who can read and write with understanding. Criteria for overcrowding were adopted according to Park K 18 $8^{\text {th }}$ edition, 2005 according to available floor space area of the room per person. ${ }^{(5)}$ General cleanliness of the house was assessed based upon observational findings on fly density, refuse disposal, drainage system and mosquito breeding.(8) Nutritional status is assessed based on WHO weight for age criteria (2006).(9) Immunized children are those who received even one dose of Vaccine included in National Immunization Schedule. Episodes are calculated based on at least period of three consecutive days free from symptoms and signs between next attacks. Chi-square test was applied to test for significance in the difference and SPSS 20 version and Epi Info Version 7 were used for analysis.

RESULTS: Table 1 show that out of 390 children, most of them are living in nuclear family (91.5\%), kutcha type of house (96.7\%) and $77.2 \%$ of them also lived in houses where there is overcrowding as per available floor space area. There is equal proportion of sex in the study. On observatory finding of general cleanliness of houses including courtyard $85.9 \%$ of children are living in satisfactory houses. Of all children $79.8 \%$ of them were of normal nutritional status for their age and $80.5 \%$ children have per capita income $\leq$ Rs $1000 /$ month.

Table 2 shows that acute respiratory infection (ARI) is the commonest disease in the community contributing $83.6 \%$ of children at least once in three months with episode of 2.61 per child however diarrhea is the next commonest cause with $34.9 \%$ prevalence during the period with 2.03 episodes per child per 3 months.

In table 3 there is significantly increased illness (p-value $=0.0001$ ) at least once in 3 months among children above one year (95.8\%) as compared to infants $(77.9 \%)$ however there is no significant difference in different sexes.

DISCUSSION: ARI was the commonest disease (83.6\%) of the children during the period of three months followed by diarrhea (34.9\%), caries (16.9\%), dysentery (6.7\%), scabies (6.7\%), worm infestation (5.9\%), conjunctivitis (5.9\%), measles (3.8\%), pneumonia $(1.8 \%)$ etc. The average episodes of ARI and diarrhea are 2.61 and 2.03 per 3 months period. Similar observations were found in studies conducted by Yurembam M et al (1993)(8), Mukherjee DK (1979)(3), Nwolisa CE et al (2005)(4) and Bisrat F et al (1995)(2) where ARI was the commonest disease followed by diarrhea, however the prevalence rate of the two diseases are comparatively high in the present study. Reasons may be the unique topographical condition of the area where drainage system and latrine outlets were drained to Loktak Lake which is the main source of drinking water. Moreover, personal hygiene and environmental sanitary conditions are poor. Houses are densely built and most living rooms were overcrowded. Over and above the conditions there was an episode of flood one month before the study.

The proportion of illness among infants is comparatively less than those of above 1 years age groups $(77.9 \%$ and $96 \%$ respectively) and difference is statistically significant (pvalue $=0.0001$ ). This may be due to the fact that approximately up to 6 months almost all children have inherent immunity and also under full care and protection, therefore less chance for exposure to different environmental factors. Similar observations were found in study of Yurembam M et al (1993).(8)

CONCLUSION: From the study it appears that ARI is the commonest morbidity among underfive in rural area of Manipur. There is no association of any factors except infancy with under- 
five morbidity. It is possible that any other factors except infancy has no relationship in post flood on under-five morbidity. It has to be studied further with better study design.

Conflict of interest: None declared

\section{REFERENCES:}

1. Awasthi S and Pande V.K. Seasonal pattern of morbidities in preschool slum Children in Lucknow, North india. Ind Pediatr; 1997; 34:987-993,.

2. Bisrat F, Berhane Y, Mamo A, Asefa E. Morbidity Pattern among refugees in Eastern Ethiopia. East Afr Med J.1995;72(11):728-30.

3. Macfarlane SB. Conducting a Descriptive Survey: 2. Choosing a Sampling Strategy. Trop Doct 1997; 27(1):14-21.

4. Mukherjee D.K. A longitudinal study of the pattern of illness in under privileged Bengali Hindu Children from birth up to 18 months of age. Ind. Jour. of Pub. Health1979; 23(1):17-23.

5. Nwolisa CE and Erinangha Au. Pattern of morbidity among pre- school children attending the children's outpatient clinic of Federal Medical Center Owerri, Nigeria. Niger J. Med 2005; 14(4):378-80.

6. Park K. Parks Text Book of Preventive and Social Medicine. 18th Edn. Jabalpur. M/s Banarsidas Bhanot. 2005.

7. Sharma S and Gupta B.P. Prevalence of 'At Risk' Under-five Children in a Rural Area. Indian Journal of Community Medicine 2005;30(1): 30-31,

8. UNICEF. Investing in children. South-East Asia Report: 2004. 3-13.

9. Yurembam M, Rajkumar N, Pukhrambam B, Hijam R, K. I. and Rungsung S. Study of morbidity pattern among pre-school Children of urban \& rural areas of Manipur [Departmental research work]. Dept. of Community Medicine, RIMS; 1992.

10. WHO. WHO Child Growth Standards, weight-for-age; 2006. 
Table 1. Distribution according to different characteristics- age, per capita income and literacy status

\begin{tabular}{|c|c|c|}
\hline Characteristics & $\begin{array}{c}\text { Number } \\
(\%)\end{array}$ & Mean (SD) \\
\hline $\begin{array}{l}\text { Type of family } \\
\text { Nuclear } \\
\text { Joint }\end{array}$ & $\begin{array}{c}357(91.5) \\
33(8.5)\end{array}$ & \multirow{7}{*}{ NA } \\
\hline $\begin{array}{c}\text { Type of house } \\
\text { Kutcha } \\
\text { Pucca+ Semi pucca }\end{array}$ & $\begin{array}{c}377(96.7) \\
13(3.3)\end{array}$ & \\
\hline $\begin{array}{c}\text { Overcrowding per space area } \\
\text { Yes } \\
\text { No }\end{array}$ & $\begin{array}{c}301(77.2) \\
89(22.8)\end{array}$ & \\
\hline $\begin{array}{c}\text { General cleanliness of house including courtyard - } \\
\text { observatory findings } \\
\text { Poor } \\
\text { Satisfactory }\end{array}$ & $\begin{array}{c}55(14.1) \\
335(85.9)\end{array}$ & \\
\hline $\begin{array}{c}\text { Sex } \\
\text { Male } \\
\text { Female }\end{array}$ & $\begin{array}{l}195(50) \\
195(50)\end{array}$ & \\
\hline $\begin{array}{l}\text { Nutritional status } \\
\text { Low } \\
\text { Normal }\end{array}$ & $\begin{array}{c}79(20.3) \\
311(79.8)\end{array}$ & \\
\hline $\begin{array}{l}\text { Literacy status of mother } \\
\text { Illiterate } \\
\text { Literate }\end{array}$ & $\begin{array}{c}82(21) \\
308(79)\end{array}$ & \\
\hline $\begin{array}{l}\text { Per capita income in Rs per month } \\
\qquad \begin{array}{l}\leq 1000 \\
>1000\end{array}\end{array}$ & $\begin{array}{c}314(80.5) \\
76(19.5)\end{array}$ & $\begin{array}{l}730.27 \\
(455.8)\end{array}$ \\
\hline $\begin{array}{c}\text { Age in year } \\
<1 \\
1-2 \\
2-3 \\
3-4 \\
4-5\end{array}$ & $\begin{array}{l}77(19.7) \\
69(17.7) \\
66(16.9) \\
94(24.1) \\
84(21.5)\end{array}$ & $\begin{array}{c}30.16 \\
(17.28)\end{array}$ \\
\hline $\begin{array}{c}\text { Birth order } \\
\quad 1 \\
2 \\
3 \\
4 \\
\geq 5\end{array}$ & $\begin{array}{c}139(35.6) \\
122(31.3) \\
74(19) \\
34(8.7) \\
21(5.4)\end{array}$ & $2.19(1.22)$ \\
\hline
\end{tabular}


Table 2. Distribution of diseases encountered in the study population with episodes during last 3 months period $(\mathrm{n}=390)$

\begin{tabular}{|l|l|c|c|c|}
\hline Sl. No. & Type of diseases & $\begin{array}{c}\text { No. of children } \\
\text { affected (\%) }\end{array}$ & Frequency & $\begin{array}{c}\text { Episodes per } \\
\text { child in } 3 \\
\text { months }\end{array}$ \\
\hline 1 & ARI & $326(83.6)$ & 852 & 2.6 \\
\hline 2 & Diarrhea & $136(34.9)$ & 276 & 2 \\
\hline 3 & Caries & $66(16.9)$ & 66 & 1 \\
\hline 4 & Dysentery & $26(6.7)$ & 30 & 1.25 \\
\hline 5 & Scabies & $26(6.7)$ & 27 & 1.04 \\
\hline 6 & $\begin{array}{l}\text { Worm } \\
\text { infestation }\end{array}$ & $23(5.9)$ & 24 & 1.04 \\
\hline 7 & Conjunctivitis & $23(5.9)$ & 23 & 1 \\
\hline 8 & Measles & $15(3.8)$ & 15 & 1 \\
\hline
\end{tabular}

Table 3. Distribution of illness of children last 3 months according to their different characteristics.

\begin{tabular}{|c|c|c|c|c|}
\hline \multirow{2}{*}{\multicolumn{2}{|c|}{ Characteristics }} & \multicolumn{2}{|c|}{ Illness last 3 months } & \multirow{2}{*}{$\mathrm{p}$-value } \\
\hline & & No & Yes & \\
\hline \multirow{2}{*}{ Type of family } & Joint & $27(7.6)$ & $330(92.4)$ & \multirow{2}{*}{0.979} \\
\hline & Nuclear & $3(9)$ & $30(91)$ & \\
\hline \multirow{2}{*}{ Type of house } & Kutcha & $29(7.7)$ & $348(92.3)$ & \multirow{2}{*}{0.597} \\
\hline & Pucca+semipucca & $1(7.7)$ & $12(92.3)$ & \\
\hline \multirow{2}{*}{$\begin{array}{c}\text { Overcrowding per space } \\
\text { area }\end{array}$} & No & $8(9)$ & $81(91)$ & \multirow{2}{*}{0.601} \\
\hline & Yes & $22(7.3)$ & $279(92.7)$ & \\
\hline \multirow{2}{*}{$\begin{array}{c}\text { General cleanliness } \\
\text { ( observatory findings) }\end{array}$} & Good+ Satisfactory & $25(7.5)$ & $310(92.5)$ & \multirow{2}{*}{0.883} \\
\hline & Poor & $5(9.1)$ & $50(90.9)$ & \\
\hline \multirow{2}{*}{ Sex } & Male & $11(5.6)$ & $184(94.4)$ & \multirow{2}{*}{0.128} \\
\hline & Female & $19(9.7)$ & $176(90.3)$ & \\
\hline \multirow{4}{*}{ Birth order } & 1 & $13(9.4)$ & $126(90.6)$ & \multirow{4}{*}{$>0.05$} \\
\hline & 2 & $3(2.5)$ & $119(97.5)$ & \\
\hline & 3 & $8(10.8)$ & $66(89.2)$ & \\
\hline & $\geq 4$ & $6(10.9)$ & $49(89.1)$ & \\
\hline \multirow{2}{*}{ Nutritional status } & Under nutrition & $5(6.3)$ & $74(93.7)$ & \multirow{2}{*}{0.785} \\
\hline & Adequate & $25(8)$ & $286(92)$ & \\
\hline \multirow{2}{*}{$\begin{array}{l}\text { Literacy status of } \\
\text { mother }\end{array}$} & Illiterate & $4(4.9)$ & $78(95.1)$ & \multirow{2}{*}{0.399} \\
\hline & Literate & $26(8.4)$ & $282(91.6)$ & \\
\hline \multirow{2}{*}{ Immunization status } & No & $3(15.8)$ & $16(84.2)$ & \multirow{2}{*}{0.20} \\
\hline & Yes & $21(5.8)$ & $344(94.2)$ & \\
\hline \multirow{5}{*}{ Age in years } & $<1$ & $17(22.1)$ & $60(77.9)$ & \multirow{5}{*}{0.0001} \\
\hline & $1-2$ & $2(2.9)$ & $67(97.1)$ & \\
\hline & $2-3$ & $3(4.5)$ & $63(95.5)$ & \\
\hline & $3-4$ & $5(5.3)$ & $89(94.7)$ & \\
\hline & $4-5$ & $3(3.6)$ & $81(96.4)$ & \\
\hline
\end{tabular}

